\title{
2021 Handbook of Florida Water Regulation: Agricultural Best Management Practices ${ }^{1}$
}

\author{
Michael T. Olexa, Tatiana Borisova, and Jana Caracciolo²
}

\section{Preface}

This handbook is designed to provide an accurate, current, and authoritative summary of the principal federal and state (Florida) laws that directly or indirectly relate to agriculture. This handbook provides a basic overview of the many rights and responsibilities that farmers and farmland owners have under both federal and state laws as well as the appropriate contact information to obtain more detailed information. However, the reader should be aware that because the laws, administrative rulings, and court decisions on which this handbook is based are subject to constant revision, portions of this publication could become outdated at any time. Several details of cited laws are also left out due to space limitations. This handbook is provided as an educational text for those interested in water use and water resource issues in Florida.

This handbook is distributed with the understanding that the authors are not engaged in rendering legal or other professional advice, and the information contained herein should not be regarded as a substitute for professional advice. This handbook is not all inclusive in providing information to achieve compliance with the federal and state laws and regulations governing water protection. For these reasons, the use of these materials by any person constitutes an agreement to hold harmless the authors, the UF/IFAS Center for Agricultural and Natural Resource Law, UF/IFAS Extension for any liability claims, damages, or expenses that may be incurred by any person as a result of reference to or reliance on the information contained in this handbook. Note: UF/IFAS is the acronym for University of Florida, Institute of Food and Agricultural Sciences.

\section{Agricultural BMP Overview}

Farmers interested in stewardship activities (that protect natural resources and can often benefit production), as well as farmers interested in limiting their exposure to unwanted penalties and liabilities related to the potential impact on water resources, should utilize agricultural best management practices (BMPs).

While agencies may offer slightly different definitions of BMPs, generally BMPs are management and cultural practices that are intended to help farmers to get the most beneficial use out of their land while preserving regional water resources. These practices are defined by research and field testing to be effective and practicable methods. BMPs can help achieve agricultural production and water conservation goals and reduce or prevent pollution loading to surface and ground water.

Examples of BMPs include specific fertilizer application practices, irrigation system retrofitting, and agricultural water conservation to prevent nutrient pollution loading to surface and ground water. BMPs change with the emergence of new technologies, making it important to regularly

1. This document is FE600, one of a series of the Food and Resource Economics Department, UF/IFAS Extension. Original publication date October 1998. Revised June 2017 and April 2021. Visit the EDIS website at https://edis.ifas.ufl.edu for the currently supported version of this publication.

2. Michael T. Olexa, professor, Food and Resource Economics Department, and director, UF/IFAS Center for Agricultural and Natural Resource Law; Tatiana Borisova, associate professor, Food and Resource Economics Department; and Jana Caracciolo, student; UF/IFAS Extension, Gainesville, FL 32611.

The Institute of Food and Agricultural Sciences (IFAS) is an Equal Opportunity Institution authorized to provide research, educational information and other services

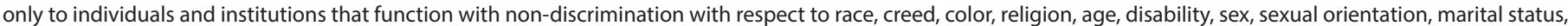

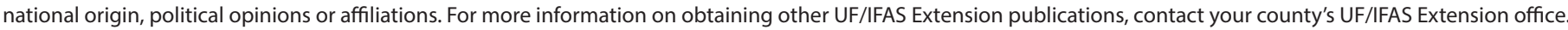
U.S. Department of Agriculture, UF/IFAS Extension Service, University of Florida, IFAS, Florida A \& M University Cooperative Extension Program, and Boards of County Commissioners Cooperating. Nick T. Place, dean for UF/IFAS Extension. 
interact with the local UF/IFAS Extension Office (http:// sfyl.ifas.ufl.edu/map/index.shtml), Soil and Water Conservation District (https://afcd.us/florida-swcd-districts/), Florida Farm Bureau (https://www.thisfarmcares.org/careseligibility), and regional and state agencies (see sections below).

Several regional, state, and federal agencies implement programs assisting farmers with BMP information and implementation. Participation in the program is voluntary; however, in basin management action plan ("BMAP") areas farmers are limited to either participating in the Florida Department of Agriculture and Consumer Services (FDACS) BMP program or implementing a water-quality monitoring program. Agencies can offer cost-share funding and technical assistance to farmers for designing and implementing BMPs.

\section{FDACS Agricultural BMP Programs}

To address water quality issues, The Office of Agricultural Water Policy (OAWP) of the Florida Department of Agriculture and Consumer Services (FDACS) is actively involved in the development of BMP manuals for specific agricultural commodities, with BMPs addressing both water quality and water conservation. BMPs are defined as "individual or combined practices determined through research, field testing, and expert review to be the most effective and practicable means for improving water quality, taking into account economic and technological considerations" (copied from FDACS "Agriculture and Water Quality"). The FDACS BMP manuals for different agricultural operations are available at the FDACS website (https://www.fdacs.gov/Agriculture-Industry/Water/ Agricultural-Best-Management-Practices).

To enroll in the FDACS BMP program, locate and contact your FDACS BMP coordinator to schedule a meeting. The coordinator will provide a free assessment of your operation to determine which BMPs from the relevant FDACS BMP manuals apply to you. Next, the coordinator will supply a BMP checklist and Notice of Intent form to be signed. The farmer needs to keep a copy of the checklist and signed Notice of Intent, and to implement and maintain the applicable BMPs and keep required records.

Enrollment in the FDACS BMP program provides producers a presumption of compliance with state water quality standards. Enrollment into the program also makes producers eligible for cost-share program.
The Implementation Verification program under the Clean Waterways Act of 2020 requires FDACS to conduct implementation verification visits to enrolled parcels every two years. To demonstrate that BMPs are implemented properly, farmers are required to provide FDACS records related to nitrogen and phosphorus applications. On the regional level, FDEP requires summaries of BMAP area records. For more information on the implementation verification process, see the UF/ IFAS blog (http://blogs.ifas.ufl.edu/clue/2020/08/06/ senate-bill-712-overview-letter-for-agricultural-producers/).

An interactive map to locate your FDACS BMP coordinator is available online (http://www.freshfromflorida.com/Divisions-Offices/Agricultural-Water-Policy/ Agricultural-Best-Management-Practices).

You can also contact your local UF/IFAS Extension Office to get more information and assistance (http://sfyl.ifas.ufl. edu/map/index.shtml).

\section{FDEP Agricultural BMAPs and BMPs}

The FDACS agricultural BMP program is linked with state water quality policies. The Florida Department of Environmental Protection (FDEP) is leading the development of plans to restore water quality in rivers, lakes, and estuaries referred to as Basin Management Action Plans (BMAP). Simply put, these plans are plans of action to reduce pollution loading and meet the total limit on pollution (defined as Total Maximum Daily Load [TMDL]). When FDEP adopts BMAPs that include agriculture practices, producers must either implement FDACS-adopted BMPs or conduct monitoring programs (prescribed by FDEP or the regional Water Management District) to show they are not violating water-quality standards. In contrast, implementation of BMPs can give producers the presumption of compliance with state water quality standards and eligibility for costshare funding.

For more information on BMAPs, see http://www.dep.state. fl.us/water/watersheds/bmap.htm.

\section{NRCS Agricultural BMP Programs}

Among the programs authorized by the federal Farm Bill and administered by the United States Department of Agriculture (USDA), Natural Resources Conservation Service (NRCS), several provide assistance to producers and landowners with practices that help improve and protect water quality and quantity. The practices include 
activities that conserve natural resources while improving agricultural productivity, as well as wetland restoration practices and temporal or permanent land retirement. These voluntary programs include the Environmental Quality Incentive Program (EQIP), Agricultural Conservation Easement Program (ACEP), and Conservation Stewardship Program (CSP). To find your local NRCS office and learn more about the programs available in your area, visit https://offices.sc.egov.usda.gov/locator/app.

To find out more about the Farm Bill (also referred to as the Agricultural Improvement Act), see the following resources:

- USDA Economic Research Service. Agricultural Improvement Act of 2018: Highlights and Implications. https://www.ers.usda.gov/agriculture-improvement-actof-2018-highlights-and-implications/

- Mylavarapu, R., Hines, K., and T. Borisova. 2017. Cost Share Programs for Florida's Agricultural Producers and Landowners. UF/IFAS EDIS Publication \#SL264 (https:// edis.ifas.ufl.edu/publication/SS485).

The complete text of 2018 Farm Bill can be found at: https:// www.congress.gov/115/bills/hr2/BILLS-115hr2enr.pdf

\section{FWMD Agricultural BMP Programs}

Florida's five Water Management Districts (FWMDs) offer funding support for agricultural producers to improve water use efficiency and protect the quality of surface and ground water. Participation in the programs is voluntary. If funding support for agricultural BMPs is provided by the FWMDs, the districts may require revising consumptive water use permits (i.e., permits allowing producers to withdraw water for irrigation). To find the FWMD that covers your area, see http://www.dep.state.fl.us/secretary/ watman/.

An example of an available cost-share program is the Facilitating Agricultural Resource Management Systems (FARMS) program in the Southwest Florida Water Management District (SFWMD). The FARMS program is a cost-share reimbursement program to promote surface water and groundwater resource sustainability for projects that promote tailwater recovery and/or surface water use, while reducing groundwater withdrawals. For more information on the FARMS program and how to qualify for funding from this and other FWMD programs, please see the following links:

- Northwest Florida WMD: http://www.nwfwater.com/ Water-Resources/Funding-Programs
- Suwannee River WMD: https://www.mysuwanneeriver. com/366/Agricultural-Cost-Share-Program

- St. Johns River WMD: http://www.sjrwmd.com/funding/

- Southwest Florida WMD's Facilitated Agricultural Resource Management Systems (FARMS) program: https://www.swfwmd.state.fl.us/business/agriculture/ farms-programs

- Southwest Florida WMD's Mini-FARMS program: https://www.swfwmd.state.fl.us/business/agriculture/ mini-farms

- South Florida WMD’s cooperative funding program: https://www.sfwmd.gov/doing-business-with-us/ coop-funding

- South Florida WMD's Dispersed Water Management/Water Farming program: https://www.sfwmd.gov/our-work/ water-storage-strategies

\section{Acknowledgments}

The authors are indebted to the personnel of both state and federal agencies who provided their time and advice in the preparation of this handbook. We acknowledge Carol Fountain and Susan Gildersleeve at the University of Florida for their assistance in editing this handbook. We also acknowledge funding received for updating this publication from the James S. and Dorothy F. Wershow Agricultural Law Endowment. 